University of Nebraska - Lincoln

DigitalCommons@University of Nebraska - Lincoln

\title{
Inhibition of cysteine and aspartyl proteinases in the alfalfa weevil midgut with biochemical and plant-derived proteinase inhibitors
}

\author{
Stephen E. Wilhite \\ United States Department of Agriculture \\ Thomas C. Elden \\ United States Department of Agriculture \\ Joze Brzin \\ Jozef Stefan Institute \\ Ann C. Smigocki \\ United States Department of Agriculture
}

Follow this and additional works at: https://digitalcommons.unl.edu/usdaarsfacpub

Part of the Agricultural Science Commons

Wilhite, Stephen E.; Elden, Thomas C.; Brzin, Joze; and Smigocki, Ann C., "Inhibition of cysteine and aspartyl proteinases in the alfalfa weevil midgut with biochemical and plant-derived proteinase inhibitors" (2000). Publications from USDA-ARS / UNL Faculty. 378.

https://digitalcommons.unl.edu/usdaarsfacpub/378

This Article is brought to you for free and open access by the U.S. Department of Agriculture: Agricultural Research Service, Lincoln, Nebraska at DigitalCommons@University of Nebraska - Lincoln. It has been accepted for inclusion in Publications from USDA-ARS / UNL Faculty by an authorized administrator of DigitalCommons@University of Nebraska - Lincoln. 


\title{
Inhibition of cysteine and aspartyl proteinases in the alfalfa weevil midgut with biochemical and plant-derived proteinase inhibitors
}

\author{
Stephen E. Wilhite a, Thomas C. Elden ${ }^{\text {a }}$, Joze Brzin ${ }^{\text {b }}$, Ann C. Smigocki ${ }^{\mathrm{c}, *}$ \\ a Soybean and Alfalfa Research Laboratory, Agricultural Research Service, US Department of Agriculture, Beltsville, MD 20705, USA \\ ${ }^{\mathrm{b}}$ Department of Biochemistry and Molecular Biology, Jozef Stefan Institute, Jamova 39, SI-1000 Ljubljana, Slovenia \\ ${ }^{\mathrm{c}}$ Molecular Plant Pathology Laboratory, Agricultural Research Service, US Department of Agriculture, Beltsville, MD 20705, USA
}

Received 20 September 1999; received in revised form 20 April 2000; accepted 26 April 2000

\begin{abstract}
Proteolytic activities in alfalfa weevil (Hypera postica) larval midguts have been characterized. Effects of pH, thiol activators, low-molecular weight inhibitors, and proteinase inhibitors (PIs) on general substrate hydrolysis by midgut extracts were determined. Hemoglobinolytic activity was highest in the acidic to mildly acidic $\mathrm{pH}$ range, but was maximal at $\mathrm{pH} 3.5$. Addition of thiolactivators dithiothreitol (DTT), 2-mercaptoethanol (2-ME), or L-cysteine had little effect on hemoglobin hydrolysis at pH 3.5, but enhanced azocaseinolytic activity two to three-fold at $\mathrm{pH}$ 5.0. The broad cysteine PI E-64 reduced azocaseinolytic activity by $64 \%$ or $42 \%$ at pH 5 in the presence or absence of $5 \mathrm{mM}$ L-cysteine, respectively. Inhibition by diazomethyl ketones, Z-Phe-Phe-CHN 2 and Z-Phe-Ala- $\mathrm{CHN}_{2}$, suggest that cathepsins L and B are present and comprise approximately $70 \%$ and $30 \%$ of the cysteine proteolytic activity, respectively. An aspartyl proteinase component was identified using pepstatin A, which inhibited 32\% (pH 3.5, hemoglobin) and 50\% ( $\mathrm{pH} 5$, azocasein) of total proteolytic activity. This activity was completely inhibited by an aspartyl proteinase inhibitor from potato (API), and is consistent with the action of a cathepsin D-like enzyme. Hence, genes encoding PIs with specificity toward cathepsins L, B and D could potentially be effective for control of alfalfa weevil using transgenic plants. (C) 2000 Elsevier Science Ltd. All rights reserved.
\end{abstract}

Keywords: Coleoptera; Midgut proteinases; Hypera postica; Cathepsin L; Cathepsin D

\section{Introduction}

The use of genes encoding proteinase inhibitors (PIs) to transform crop plants for resistance to insect pests has been well documented (for reviews, see Jouanin et al., 1998; Schuler et al., 1998). PIs occur naturally in a number of plant species and are believed to have a role in the natural defense of plants against insect pests (Green and Ryan, 1972). The ability of PIs to interfere with insect growth and development has been attributed to their capacity to bind to, and thereby inhibit the action of insect digestive proteinases (reviewed by Jongsma and Bolter, 1997). Since there exists significant variation among the types and properties of endo- and exo-proteinases utilized by insects for dietary purposes

* Corresponding author. Tel.: +1-301-504-5848; fax: +1-301-5045728.

E-mail address: smigocki@asrr.arsusda.gov (A.C. Smigocki). (reviewed by Terra and Ferreira, 1994), and because numerous PIs of widely-ranging specificities (Keilova and Tomasek, 1976a; Abe et al., 1994; Brzin et al., 1998; Christeller et al., 1998; Pernas et al., 1998) towards these proteinases are available, it is necessary to characterize the gut proteolytic activities of each individual species in order to devise a rational insect control strategy utilizing PIs.

There is a heavy reliance among insects on endoproteinases for the purpose of assimilating dietary protein. Endoproteinases belong to one of four groups based on the amino acid residue or metal ion involved in peptide bond catalysis (Barrett, 1986): (i) serine, (ii) cysteine (or thiol), (iii) aspartyl (or carboxyl), and (iv) metalloproteinases. Insects having a midgut $\mathrm{pH}$ in the neutral or alkaline range generally rely on serine proteinases that are trypsin-, chymotrypsin-, or elastase-like, based on their similarity to mammalian enzymes. In contrast, insects having acidic or mildly acidic midguts generally utilize cysteine proteinases, such as cathepsins B, $\mathrm{H}$ and 
$\mathrm{L}$, and/or aspartyl proteinases such as cathepsin D and pepsin (Terra and Ferreira, 1994). While there exists a pattern of predominance involving serine proteinases in Diptera and Lepidoptera (Applebaum, 1985; Christeller et al., 1992; Terra and Ferreira, 1994), and cysteine proteinases in Coleoptera (Murdock et al., 1987), exceptions are common. Of particular relevance here, Coleoptera have been demonstrated to also utilize serine and aspartyl proteinases (Christeller et al., 1989; Thie and Houseman, 1990; Bonade-Bottino et al., 1999). Such complexity that often involves two or more proteinase classes necessitates the use of multiple PIs for insect control, as uninhibited proteinases can degrade the ingested PI and compensate for the activity lost as a result of PI action on sensitive proteinases (Broadway, 1996a; Jongsma and Bolter, 1997; Girard et al., 1998a,b).

This study characterizes the major midgut proteinases of larval alfalfa weevil, Hypera postica Gyllenhal (Coleoptera: Curculionidae), a major pest of alfalfa for which traditional breeding techniques for resistance have failed. The effect of $\mathrm{pH}$, low-molecular weight inhibitors, and plant-derived PIs on proteinase activity in midgut extracts is presented.

\section{Materials and methods}

\subsection{Materials}

Azocasein, hemoglobin, L-trans-epoxysuccinylleucylamido(4-guanidino)butane (E-64), leupeptin, pepstatin A, phenylmethylsulfonyl fluoride (PMSF), and soybean trypsin-chymotrypsin inhibitor (Bowman-Birk inhibitor I, BBI) were from Sigma Chemical Co. (St. Louis, MO). Peptidyl-diazomethane inhibitors, Z-PhePhe- $\mathrm{CHN}_{2}$ and Z-Phe-Ala-CHN ${ }_{2}$, were obtained from Bachem California (Torrance, CA). Oryzacystatin I (OCI) (Abe et al., 1987) was expressed as s glutathione S-transferase (GST) fusion protein in Escherichia coli strain BL21 (Stratagene) as previously described (Michaud et al., 1994). Aspartyl proteinase inhibitor (API) was purified from potato as previously described (Kreft et al., 1997) and consisted of several isoforms (Ritonja et al., 1990; Barlic-Maganja et al., 1992; Strukelj et al. 1992, 1995; Kreft et al., 1997) of potato cathepsin D inhibitor (PDI) (Keilova and Tomasek, 1976b).

\subsection{Insects}

Alfalfa weevil larvae used in this study were secondgeneration laboratory-reared, derived from eggs of nondiapausing field-collected adults, as described by Ratcliffe and Elgin (1987). To assure an ample supply of eggs, successive generations of newly-emerged adults were fed bouquets of greenhouse-grown alfalfa foliage for $2 \mathrm{wk}$, and then placed in cold storage $\left(4^{\circ} \mathrm{C}\right)$ on $2 \%$ $(\mathrm{w} / \mathrm{v})$ sugar water for more than $8 \mathrm{wk}$. After removal from storage, adults were fed alfalfa foliage for $3 \mathrm{wk}$, after which time they began oviposition (Elden, 1995a). Larvae were reared on flats of greenhouse-grown alfalfa. All insects were reared in a walk-in environmental growth chamber maintained under a photoperiod of 8:16 (L:D) $\mathrm{h}$ at $24 \pm 1^{\circ} \mathrm{C}$ and $50-90 \%$ r.h.

Alfalfa weevil midguts were excised from late third and early fourth instar larvae under magnification. After splitting the body cavity lengthwise, the midgut was removed excluding the fore- and hindgut. Only full guts containing visible contents were used. Midguts were immediately placed in a micro-eppendorf tube embedded in dry ice. Samples consisting of 50 midguts were frozen at $-80^{\circ} \mathrm{C}$ for later extract preparation.

\subsection{Midgut extract preparation}

This procedure was modified from Michaud et al. (1995). Frozen midguts were thawed on ice and homogenized following the addition of ice-cold citrate-phosphate buffer ( $\mathrm{pH}$ 6.0) containing $0.1 \%$ Triton X-100. Homogenates were microfuged at $16,000 \mathrm{~g}$ for $5 \mathrm{~min}$ at $4^{\circ} \mathrm{C}$. Supernatants were transferred to fresh tubes and pellets re-extracted as above. Pooled supernatants were microfuged one final time for $30 \mathrm{~min}$ at $4^{\circ} \mathrm{C}$. Cleared supernatants were concentrated, when necessary, using microcon-3 microconcentrators (Amicon, Inc., Beverly, MA) and applied to Bio-Gel P6 columns (Bio-Rad, Hercules, CA) at $100 \mu \mathrm{l}$ per column. Flow-through was collected, aliquoted, and stored at $-20^{\circ} \mathrm{C}$ following protein determination using the Bio-Rad Protein Assay with bovine serum albumin (BSA) as a standard. Only residual proteinase activity $(<1 \%$ of total $)$ was detected in the pellet following this extraction method.

\subsection{Proteinase and PI assays}

Azocaseinase determinations were adapted from Sarath et al. (1989) and Barrett and Kirschke (1981) and Barrett and Kirschke (1981). Enzyme extracts (containing from 5-20 $\mu \mathrm{g}$ protein) were combined with $5 \mu \mathrm{l}$ of $2.4 \%$ Triton X-100, $34 \mu \mathrm{g}$ of BSA, and $100 \mathrm{mM}$ citrate-phosphate buffer at the appropriate $\mathrm{pH}$ to yield $40 \mu$ l. Eighty-microliters of $2 \%$ (w/v) azocasein (prepared in citrate-phosphate buffer of desired $\mathrm{pH}$ ) was added, and the final reaction mix was incubated for $3 \mathrm{~h}$ at $37^{\circ} \mathrm{C}$. The final concentration of reactants was $0.1 \%$ Triton X-100, $0.028 \%(\mathrm{w} / \mathrm{v}) \mathrm{BSA}$, and $1.33 \%(\mathrm{w} / \mathrm{v})$ azocasein in the $120 \mu \mathrm{l}$ reaction. Reactions were terminated by adding $300 \mu \mathrm{l}$ of $10 \%(\mathrm{w} / \mathrm{v})$ trichloroacetic acid. Samples were incubated on ice for $10 \mathrm{~min}$ followed by sedimentation of undigested substrate by centrifugation at $16,000 \mathrm{~g}$ for $5 \mathrm{~min}$ at room temperature (RT). Super- 
natants $(\sim 380 \mu \mathrm{l})$ containing TCA-soluble peptide fragments were transferred to methacrylate cuvettes (Fisher Scientific) and their absorbance $(A)$ measured at $335 \mathrm{~nm}$ using a Beckman DU-70 spectrophotometer. The $A_{335}$ of blanks incubated for $3 \mathrm{~h}$ at $37^{\circ} \mathrm{C}$, which consisted of complete reaction mixtures minus extract, were used for background subtraction to account for spontaneous substrate degradation.

Activators and PIs were included, when appropriate, in the $40 \mu \mathrm{l}$ reaction mix prior to substrate addition. Concentrations of activators and inhibitors refer to their concentration in the final $120 \mu \mathrm{l}$ reaction. For inhibition assays, the $40 \mu \mathrm{l}$ reaction mix was pre-incubated approximately $5 \mathrm{~min}$ at $37^{\circ} \mathrm{C}$ to allow for the proteinaseinhibitor interaction prior to substrate addition.

Due to the insolubility of azocasein below $\mathrm{pH} 4.5$, hemoglobin was used as the substrate for determination of $\mathrm{pH}$ optimum and for thiol-activation and inhibitor assays carried out at $\mathrm{pH} 3.5$. The assay for hemoglobin proteolysis was based on the method of Houseman and Downe (1983). It was conducted in the same manner as the azocasein assay with the following modifications. The volume of reactants prior to the addition of $40 \mu \mathrm{l}$ of $2 \%(\mathrm{w} / \mathrm{v})$ hemoglobin (prepared in $0.15 \mathrm{M} \mathrm{NaCl}$ ) was $80 \mu \mathrm{l}$. Thus, the final concentration of reactants was $0.1 \%$ Triton X-100, $0.028 \%(\mathrm{w} / \mathrm{v}) \mathrm{BSA}$, and $0.67 \%$ $(\mathrm{w} / \mathrm{v})$ hemoglobin in the $120 \mu \mathrm{l}$ reaction mix. Reactions were terminated by the addition of $300 \mu$ trichloroacetic acid and the absorbance measured at $280 \mathrm{~nm}$. We define one unit of enzyme activity as being the amount of enzyme that will produce an absorbance change of 1.0 $\mathrm{h}^{-1}$ in a $1 \mathrm{~cm}$ cuvette, under the conditions of the assay. Preliminary experiments were conducted to ensure that all determinations were made within the linear range (by plotting extract quantity vs absorbance) of the assay using both substrates.

\section{Results}

\subsection{Proteolytic activity in alfalfa weevil midguts}

Proteolytic activity in extracts from weevil larvae was measured over $\mathrm{pH}$ values ranging from 2.5 to 10.0 (Fig. 1) with hemoglobin as substrate. The overall pattern of activity observed indicates the presence of proteolytic enzymes active in the acidic and mildly-acidic range. This is consistent with aspartyl and cysteine proteinases that generally have $\mathrm{pH}$ optimums in the range of 2-5 and 4-7, respectively. Serine and metalloproteinases have optimums at $\mathrm{pH}$ values of 7-9 (Barrett, 1977a; Storey and Wagner, 1986) and, therefore, do not appear to be major constituents in the extract. Maximal activity using this assay was observed at $\mathrm{pH} 3.5$ with approximately $50 \%$ of the activity remaining at $\mathrm{pH} 5.0$. The absence of any measurable hemoglobinolytic activity at

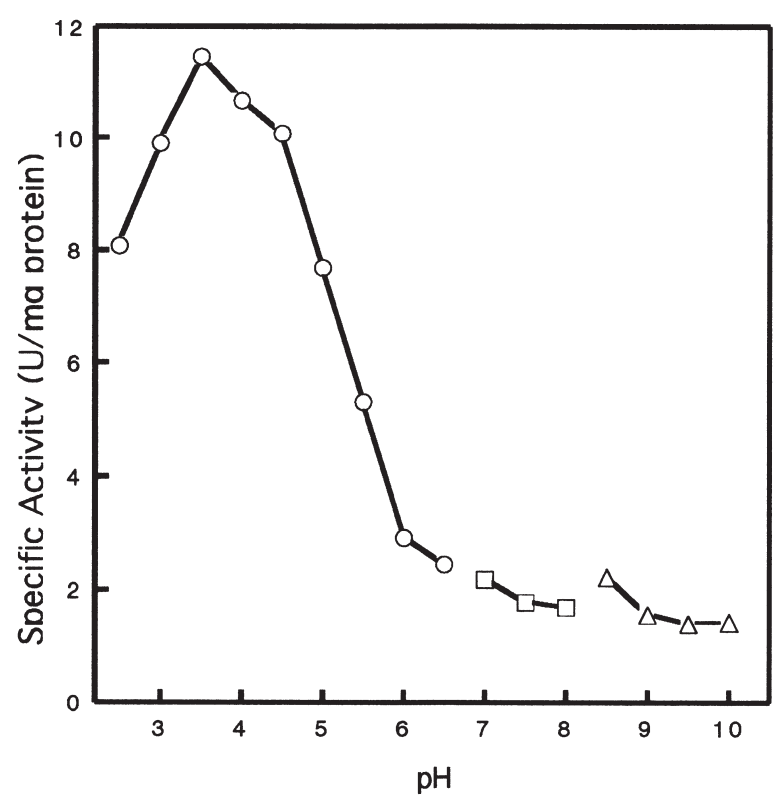

Fig. 1. Effect of $\mathrm{pH}$ on hemoglobin hydrolysis by H. postica larval midgut homogenate. Buffers were citrate-phosphate $(\bigcirc)$, phosphate $(\square)$, or glycine- $\mathrm{NaOH}(\triangle)$. The experiment was repeated twice in replicates of two and the average specific activity of a single experiment graphed. Standard errors were less than $5 \%$ of the average for all treatments.

$\mathrm{pH} \geq 7$ is consistent with what we have also observed utilizing azocasein as substrate (data not shown).

Since one of the most important diagnostic features of cysteine proteinases is enhanced activity in the presence of thiol compounds (Storey and Wagner, 1986), we examined the effect of $1 \mathrm{mM}$ or $5 \mathrm{mM}$ dithiothreitol (DTT), 2-mercaptoethanol (2-ME), or L-cysteine at $\mathrm{pH}$ 3.5 and $\mathrm{pH} 5.0$ (Table 1). Considerable activation occurred among all treatments at $\mathrm{pH} 5.0$ with azocasein as substrate, with the highest level of activation (3.3-fold

Table 1

Effect of thiol activators on $H$. postica midgut proteinase activity

\begin{tabular}{llll}
\hline Activator $^{\mathrm{b}}$ & & \multicolumn{2}{l}{ Fold-increase in activity $^{\mathrm{a}}$} \\
\cline { 3 - 4 } & & $\mathrm{pH} \mathrm{3.5}$ & $\mathrm{pH} \mathrm{5.0}$ \\
\hline Dithiothreitol & $1 \mathrm{mM}$ & $1.03 \pm 0.08$ & $2.11 \pm 0.06$ \\
& $5 \mathrm{mM}$ & $1.11 \pm 0.04$ & $1.88 \pm 0.02$ \\
2-Mercaptoethanol & $1 \mathrm{mM}$ & $0.85 \pm 0.02$ & $1.68 \pm 0.07$ \\
& $5 \mathrm{mM}$ & $0.78 \pm 0.02$ & $1.83 \pm 0.06$ \\
L-cysteine & $1 \mathrm{mM}$ & $1.13 \pm 0.04$ & $1.85 \pm 0.03$ \\
& $5 \mathrm{mM}$ & $1.20 \pm 0.04$ & $3.30 \pm 0.35$ \\
\hline
\end{tabular}

a Activity values are given as fold-increase compared to control without activator \pm SE derived from averaging the results of two separate experiments. Hemoglobin or azocasein was used as substrate at $\mathrm{pH}$ 3.5 and 5.0, respectively.

b Reaction mixtures consisted of midgut extract, citrate-phosphate buffer at given $\mathrm{pH}, 1 \mathrm{mM}$ EDTA, $0.1 \%$ Triton X-100, 0.028\% (w/v) BSA, $1 \mathrm{mM}$ or $5 \mathrm{mM}$ activator, and $0.67 \%(\mathrm{w} / \mathrm{v})$ hemoglobin or $1.33 \%$ $(\mathrm{w} / \mathrm{v})$ azocasein in the final $120 \mu \mathrm{l}$ reaction volume. 
increase) occurring in the presence of $5 \mathrm{mM} \mathrm{L}$-cysteine. Little activation, or even inhibition in the case of 2-ME, was evident at $\mathrm{pH} 3.5$ with hemoglobin as substrate. Inhibition of aspartyl proteinases, such as cathepsin D, by thiol compounds has been reported previously (Barrett, 1977b; Thie and Houseman, 1990), and may explain the inhibition by 2-ME.

\subsection{Class-specific inhibition of proteolytic activity}

The presence of aspartyl and cysteine proteinases in weevil midgut homogenates was further examined at $\mathrm{pH}$ 3.5 and 5.0 by adding low-molecular weight inhibitors known to specifically inhibit these proteinases. Pepstatin A (PEP) and E-64 are known to be largely specific towards aspartyl (Barrett, 1977b) and cysteine proteinases (Hanada et al., 1978; Barrett et al., 1982), respectively. The inhibition pattern obtained with these inhibitors without added thiol activator is presented in Fig. 2A. At $\mathrm{pH}$ 3.5, PEP and E-64 treatment resulted in a reduction in total hemoglobinolytic activity of about 32 and $33 \%$, respectively, vs reductions in azocaseinolytic activity of approximately 50 and $42 \%$ for the respective inhibitors at $\mathrm{pH}$ 5.0. Adding both inhibitors simultaneously to the reaction mixture indicates that aspartyl and cysteine proteinases together account for approximately $80 \%$ of the total midgut activity at either $\mathrm{pH}$. PMSF, a serine PI (Barrett, 1977a), did inhibit the extract by as much as $20-30 \%$ when tested at $\mathrm{pH} 5.0$ (data not shown); however, this $\mathrm{pH}$ is inconsistent with the expected activity range of serine proteinases, and PMSF is known to inhibit cysteine proteinases (Storey and Wagner, 1986) in the absence of reductants. Furthermore, an inhibitor of both cysteine and serine proteinases (leupeptin) (Barrett and Kirschke, 1981) gave a similar pattern and level of inhibition as E-64 at concentrations ranging from $0.1-200 \mu \mathrm{M}$ (data not shown). This is inconsistent with a serine-like proteolytic activity, as leupeptin would be expected to exceed the inhibition of E-64 if both classes of proteinases were present in the extract. The metalloproteinase inhibitor EDTA (Barrett, 1977a) did not inhibit proteolytic activity at either $\mathrm{pH}$ when included at $1 \mathrm{mM}$ or $5 \mathrm{mM}$ (data not shown). Inhibition experiments were not conducted at higher $\mathrm{pH}$ values due to the absence of measurable hemoglobinolytic or azocaseinolytic activity at $\mathrm{pH} \geq 7$.

The absolute level of inhibition obtained with each treatment varied with several factors that included the concentration of inhibitor, duration of extract-inhibitor co-incubation prior to substrate addition, presence or absence of reducing agent in the reaction, and the type of substrate (data not shown). Both pepstatin A and E64 were highly potent, exerting most of their effect at concentrations below $1.0 \mu \mathrm{M}$. Although co-incubation of inhibitor and extract prior to addition of the substrate generally resulted in more inhibition, it was necessary
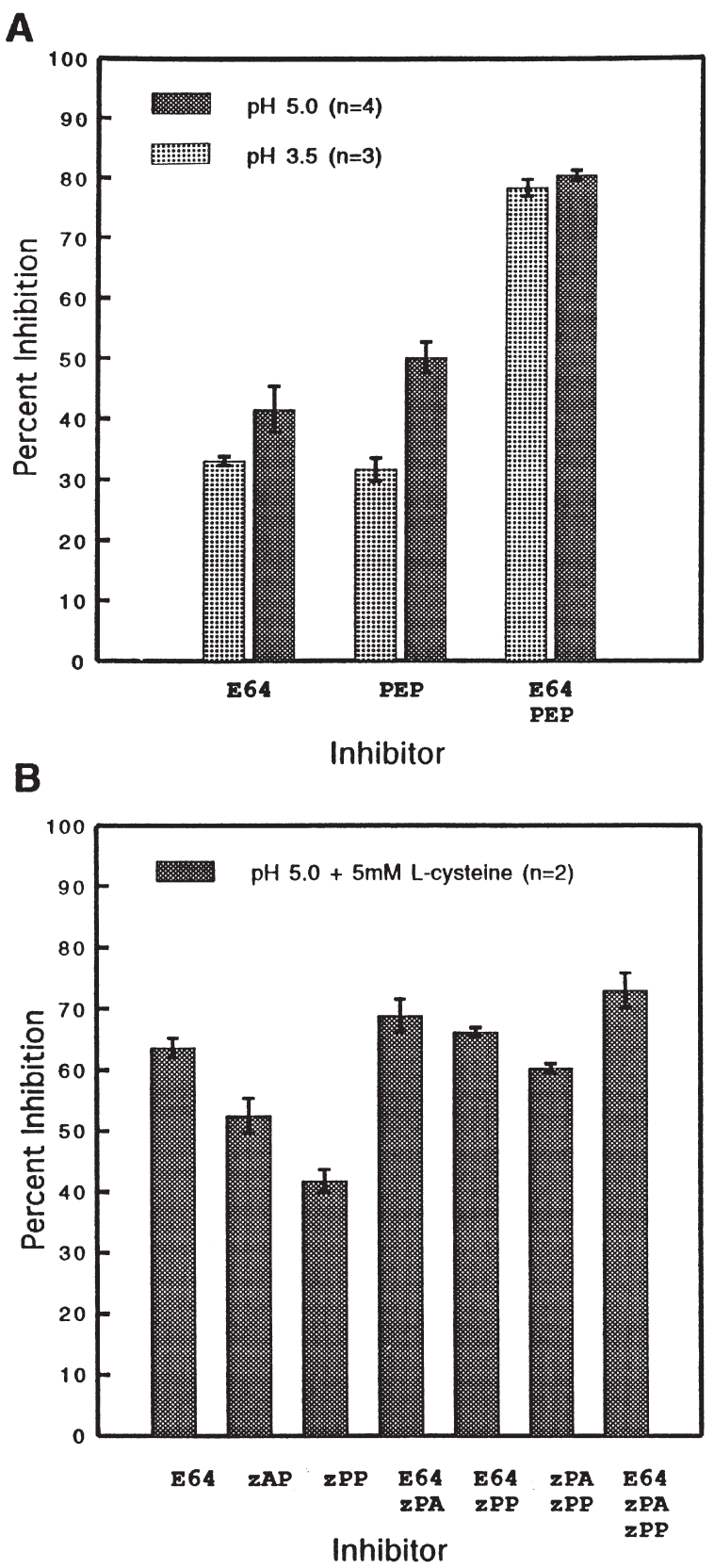

Fig. 2. Inhibition of proteolytic activity in larval midgut homogenates. (A) Inhibition of proteinases by class-specific proteinase inhibitors at both $\mathrm{pH} 3.5$ and $\mathrm{pH}$ 5.0. (B) Inhibition of proteinases with diazomethyl ketone inhibitors at $\mathrm{pH} 5.0$ in the presence of $5 \mathrm{mM} \mathrm{L}$ cysteine. E64, L-trans-Epoxysuccinyl-leucylamido(4-guanidino) butane; PEP, pepstatin A; zPA, Z-Phe-Ala- $\mathrm{CHN}_{2}$; zPP, Z-Phe-Phe$\mathrm{CHN}_{2}$. All inhibitors were used in excess at $100 \mu \mathrm{M}$ with hemoglobin (pH 3.5) or azocasein ( $\mathrm{pH}$ 5.0) provided as substrate. Experiments were repeated $n$ times and the average percent inhibition \pm SE is presented.

to limit the duration of co-incubation and include BSA in the reaction in order to minimize auto-degradation of proteolytic activity in the sample. Consequently, the maximum level of inhibition reported is not necessarily the maximum level of inhibition achievable. Inclusion of reducing agent resulted in a relative shift in the pro- 
minence of cysteine proteinases in the extract, as reflected by comparatively higher levels of E-64 inhibition. This effect, however, was much more prominent when azocasein was supplied as the substrate, as thiol activation was substantially less with hemoglobin.

The nature of the cysteine proteinase fraction of activity belonging to the crude extract was examined by employing two irreversible diazomethyl ketone inhibitors specific to the cysteine proteinase cathepsins B and L (Shaw and Green, 1981; Riemann et al., 1982). ZPhe-Ala- $\mathrm{CHN}_{2}$ (zPA) and Z-Phe-Phe-CHN ${ }_{2}$ (zPP) are both very effective inhibitors of cathepsin $\mathrm{L}$ with apparent $k_{2 \text { nd }}$ reaction rates of $70,000 \mathrm{M}^{-1} \cdot \mathrm{s}^{-1}$ and 160,000 $\mathrm{M}^{-1} \cdot \mathrm{s}^{-1}$, respectively. However, zPA is a much better inhibitor of cathepsin $\mathrm{B}\left(k_{2 \text { nd }}\right.$ ranging from 500-2000 $\left.\mathrm{M}^{-1} \cdot \mathrm{s}^{-1}\right)$ than is zPP $\left(k_{2 \text { nd }}\right.$ about $200 \mathrm{M}^{-1} \cdot \mathrm{s}^{-1}$ ) (Barrett and Kirschke, 1981). Neither inhibitor is effective against cathepsin $\mathrm{H}$ cysteine proteinase. The effect of these inhibitors on thiol-activated extract in comparison to, or in combination with, the broad cysteine PI E-64 $\left(96,250 \mathrm{M}^{-1} \cdot \mathrm{s}^{-1}, 89,400 \mathrm{M}^{-1} \cdot \mathrm{s}^{-1}\right.$, and $4000 \mathrm{M}^{-1} \cdot \mathrm{s}^{-1}$ for cathepsins $\mathrm{L}, \mathrm{B}$, and $\mathrm{H}$, respectively) (Barrett and Kirschke, 1981) is presented in Fig. 2B. The cathepsin L-specific inhibitor, zPP, inhibited about $42 \%$ of the crude azocaseinolytic activity as compared to $64 \%$ inhibition by E-64. The inhibitor of B and L cathepsins, zPA, inhibited approximately $53 \%$ of the azocaseinolytic activity. As expected, the combination of a diazomethyl ketone inhibitor with E-64 did not result in any sizable increase in inhibition as compared to E-64 alone, and the level of inhibition obtained from the combination of zPA and zPP (ca. 60\%) approximated the level of E64 inhibition.

\subsection{Inhibition by protein inhibitors}

The relative effect of several plant-derived protein inhibitors on midgut extract activity is presented in Fig. 3. The soybean trypsin/chymotrypsin inhibitor (Bowman-Birk inhibitor I, or BBI) is a known inhibitor of many serine proteinases. API inhibits cathepsin Dlike aspartyl proteinases as well as certain serine proteinases, such as trypsin and chymotrypsin, but not pepsinlike aspartyl proteinases (Keilova and Tomasek, 1976a). Rice cysteine PI oryzacystatin I (OCI) effectively inhibits cathepsins H and L, but not B (Abe et al., 1994). API and OCI (as a GST fusion protein) were highly effective against the extract. At pH 3.5, API and OCI treatments resulted in an approximate reduction in total hemoglobinolytic activity of 40 and $26 \%$, respectively, vs reductions in azocaseinolytic activity of 51 and $34 \%$ for the respective inhibitors at $\mathrm{pH}$ 5.0. These inhibitors were additive when used in combination, resulting in about 68 and 73\% inhibition at $\mathrm{pH} 3.5$ and 5.0, respectively, suggesting that they target distinct proteinase components in the extract. As expected, BBI was largely

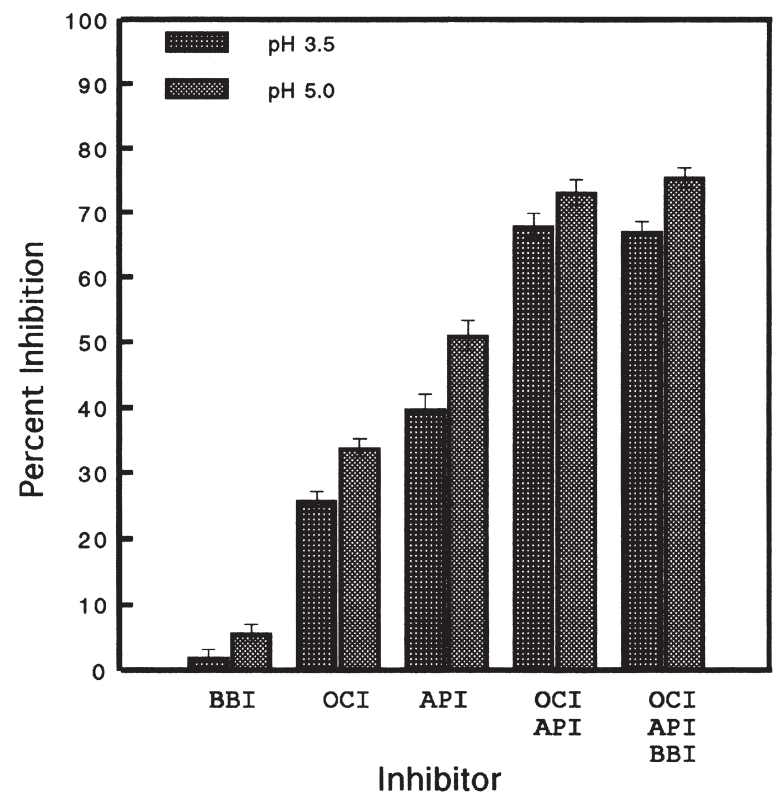

Fig. 3. Inhibition of proteolytic activity in larval midgut homogenates by plant-derived PIs. BBI, Bowman-Birk inhibitor I (soybean trypsinchymotrypsin inhibitor); OCI, oryzacystatin I; API, aspartyl proteinase inhibitor. Test levels were $50 \mu \mathrm{g}$ for OCI and BBI, and $1.4 \mu \mathrm{g}$ for API. Each reaction consisted of 6-14 $\mu \mathrm{g}$ crude midgut protein with hemoglobin $(\mathrm{pH} 3.5)$ or azocasein $(\mathrm{pH}$ 5.0) provided as substrate. Experiments were repeated three times and the average percent inhibition $\pm \mathrm{SE}$ is presented.

ineffective against the crude proteolytic activity of the extract. These results are consistent with the inhibition data obtained using the low-molecular weight inhibitors (Fig. 2) of cysteine and aspartyl proteinases.

Although Fig. 3 represents inhibition levels where the individual inhibitors are supplied at above saturation levels, both API and OCI were rather potent inhibitors based upon the concentration of inhibitor that resulted in approximately $50 \%$ of their effect $\left(\mathrm{IC}_{50}\right)$ (data not shown). Their $\mathrm{IC}_{50}$ was approximately $0.1 \mu \mathrm{g}$ GST-OCI and $0.002 \mu \mathrm{g}$ API for each microgram of crude alfalfa weevil midgut protein in the reaction. Adjusting for the molecular weight of OCI $(12,000 \mathrm{Da})$ in comparison to the total size of the GST fusion $(43,000 \mathrm{Da})$, this amounts to $0.03 \mu \mathrm{g}$ OCI for each microgram of midgut protein. By comparison, the related rice cysteine PI oryzacystatin II (Kondo et al., 1990) that strongly inhibits cathepsin $\mathrm{H}$ but is not as good an inhibitor of cathepsins $\mathrm{L}$ and B as OCI (Abe et al., 1994), inhibited the extract at levels equivalent to OCI when supplied at $\geq 50 \mu \mathrm{g}$, but had an $\mathrm{IC}_{50}$ that was more than 30 -fold higher $(1 \mu \mathrm{g}$ OCII per $\mu$ g midgut protein).

\section{Discussion}

The primary aim of this work was to identify the major digestive proteinases of $H$. postica. In a previous 
survey of Coleoptera insects by Murdock et al. (1987), $H$. postica was shown to possess proteolytic activity consistent with the action of cysteine proteinases. Methemoglobin hydrolysis by midgut homogenates at $\mathrm{pH} 5.5$ was stimulated by the addition of $5 \mathrm{mM} \mathrm{L}$-cysteine and inhibited by the alkylating agent $p$ CMB. Elden (1995b) subsequently determined that several low-molecular weight inhibitors of cysteine proteinases (E-64, $p \mathrm{HMB}$, and leupeptin) adversely affected alfalfa weevil growth and development when ingested in an in vivo bioassay. These inhibitors also reduced foliar feeding by alfalfa weevil larvae, as did the API pepstatin A, but to a lesser degree than the cysteine PIs. The present study presents a more detailed description of the digestive proteinases of $H$. postica, and identifies corresponding plant-derived inhibitors with potential use in transgenic applications.

Alfalfa weevil midguts contain a high level of proteolytic activity on general substrate up to about $\mathrm{pH} 6$ in the absence of reducing agents (Fig. 1). That this activity exists in the acidic to mildly-acidic $\mathrm{pH}$ range, and is largely blocked by the addition of inhibitors of aspartyl and cysteine proteinases (Fig. 2A), indicates that these two proteinase classes contribute the majority of proteolytic activity to the extracts. Although each class is inhibited at levels similar to one-another at the test $\mathrm{pH}$ values of 3.5 and 5.0 in vitro, their physiological importance may differ. The luminal content of alfalfa weevil midguts has been determined previously to have a $\mathrm{pH}$ of 6.6 (Elden, 1995b). Noting that this value disregards the spatial differences in $\mathrm{pH}$ that likely exist in intact insect midguts (Terra and Ferreira, 1994), and thus does not rule out the action of aspartyl proteinases, this $\mathrm{pH}$ is more consistent with the action of cysteine proteinases. Furthermore, the fraction of total proteolytic activity due to cysteine proteinases was substantially increased when reducing agent was included in the reaction (Fig. 2B). This suggests that cysteine proteinase activity could be substantial in midguts with a negative (reducing) redox potential. We speculate that the redox potential of the alfalfa weevil is reducing, as is the case of other Coleoptera beetle species believed to utilize cysteine proteinases as digestive enzymes (Murdock et al., 1987). The results of the in vivo bioassays (Elden, 1995b) using inhibitors of cysteine and aspartyl proteinases (discussed above) further support the conclusion that the cysteine class is likely the more physiologically-relevant in this insect and that the aspartyl class may have a secondary role.

Cathepsin L appears to be the major cysteine proteinase in larval midguts of the weevil. A cathepsin L-specific inhibitor, Z-Phe-Phe- $\mathrm{CHN}_{2}$, blocked approximately two-thirds of the total cysteine proteolytic activity (as measured by E-64 inhibition) in thiol-activated extracts (Fig. 2B). This is supported by the fact that a random screen of 10 clones from a cDNA library prepared using midgut-specific mRNA yielded a cDNA insert encoding a cathepsin L enzyme (GenBank
Accession \# AF157961) (Wilhite and Smigocki, unpublished). Much of the remaining one-third of cysteine proteinase activity associated with the extract is consistent with the action of cathepsin B. This is evident in the enhanced inhibition obtained with Z-Phe-Ala$\mathrm{CHN}_{2}$ compared to Z-Phe-Phe- $\mathrm{CHN}_{2}$, as well as the fact that, when combined, they approach the level of inhibition obtained with the broad cysteine PI E-64. In addition, leupeptin, which inhibits cathepsins B and L, but not H (Barrett and Kirschke, 1981), is also similar to E-64 in potency. These results support a major role for cathepsin L, a minor role for cathepsin B, and little or no role for cathepsin H. On this basis, OCI would be expected to target the major cysteine proteinase component in the weevil extract since this phytocystatin strongly inhibits cathepsin L; however, cathepsin B is not inhibited by OCI (Abe et al., 1994). This is consistent with the relationship we typically observe between OCI and E-64, as OCI inhibition is usually about twothirds to three-quarters that of E-64. Inefficient inhibition by OCII (data not shown, see Results), which has weak inhibitory activity toward cathepsin $\mathrm{B}\left(K_{\mathrm{i}}=8.2 \times 10^{-6}\right)$, is likely due to its decreased affinity for cathepsin L $\left(K_{\mathrm{i}}=3.9 \times 10^{-8}\right)$ in comparison to OCI $\left(K_{\mathrm{i}}=5.1 \times 10^{-9}\right)$ (Abe et al., 1994). A more reasonable choice would be an inhibitor with potency against both cathepsin B and $\mathrm{L}$, such as the recently characterized kidney bean phytocystatin, FSCPI 5.5 (Brzin et al., 1998).

The API preparation that we used in this study consists of several isoforms of potato cathepsin D inhibitor (PDI) that is structurally related to the soybean trypsin inhibitor family (Mares et al., 1989). It inhibits cathepsin $\mathrm{D}$ as well as the serine proteinases trypsin and chymotrypsin, but does not affect pepsin activity (Keilova and Tomasek, 1976a). That this inhibitor preparation was equal in effectiveness to that of pepstatin $A$, which inhibits pepsin as well as cathepsin D, suggests that cathepsin D is the major aspartyl proteinase in the extract. This conclusion is strengthened by the fact that a preparation of squash aspartic proteinase inhibitor (SQAPI), which inhibits pepsin but not cathepsin D (Christeller et al., 1998), had no effect on the extract (data not shown). Whether PDI will be useful in transgenic applications will hinge in large part on the effectiveness of the individual isoforms, as expressed from their cDNAs, on proteolytic activity. In addition, we have not studied the compartmentalization of enzymatic activity, so it is unknown if the ingested inhibitor would reach its target enzyme following ingestion. It is conceivable that this enzyme has a function other than initial digestion in the endoperitrophic space, as is generally true of insect midgut endoproteinases (Terra and Ferreira, 1994). Cathepsin D from rat is capable of activating cathepsin B by proteolytic cleavage of the propeptide to produce the mature form of the enzyme (Rowan et al., 1992). Zymogen activation of cathepsins $L$ and B by 
cathepsin D here would likely place this enzyme within another region of the digestive system, such as within the midgut cells themselves (Terra and Ferreira, 1994). In this case, it seems unlikely that ingested PDI would have any effect on insect growth and development.

The present study has identified cathepsins L, B, and $\mathrm{D}$ as the major proteinase forms existing in $\mathrm{H}$. postica midguts. Thus, any rational approach of insect control in transgenic plants expressing PI genes should target each of these digestive proteinases. The necessity of such a strategy has become increasingly evident with the understanding that many insects possess very effective resistance mechanisms against individual PIs. Resistance has been attributed to complex proteolytic systems, allowing the insects to degrade PIs in Coleoptera (Girard et al., 1998a) and Lepidoptera (Giri et al., 1998), and to enhance the production of inhibitor-insensitive proteinases in response to PI ingestion in Coleoptera (Girard et al., 1998b; Bonade-Bottino et al., 1999; Cloutier et al., 1999) and Lepidoptera (Broadway 1995, 1997; Jongsma et al., 1995; Broadway, 1996b; Brown et al., 1997; Wu et al., 1997). It has been suggested (Orr et al., 1994; Broadway, 1996a) that such complex mechanisms are most likely to exist in polyphagous insects having generalized feeding habits compared to oligo- or monophagous insects. Although we did not examine the issue of inhibitor-insensitivity per se, it seems likely that $H$. post$i c a$, which is oligophagous, has a proteolytic system complex enough to necessitate a defense strategy involving the co-expression of multiple PIs. A cysteine PI highly potent against cathepsins $\mathrm{L}$ and $\mathrm{B}$ should be used in combination with an aspartyl PI, such as PDI. The ability of PDI to inhibit serine proteinases is an attractive feature since these proteinases could possibly exist in the proteolytic arsenal of $H$. postica, even though we did not detect them here, or be utilized by other insect pests of alfalfa.

\section{Acknowledgements}

Special thanks to Dr Steve Gleddie (Agriculture and Agri-Food Canada) for providing the OCI and OCII GST-fusion constructs, and to Dr Gail Gasparich for producing the corresponding fusion proteins in E. coli.

\section{References}

Abe, K., Kondo, H., Arai, S., 1987. Purification and characterization of a rice cysteine proteinase inhibitor. Agric. Biol. Chem. 51, 2763-2768.

Abe, M., Abe, K., Iwabuchi, K., Domoto, C., Arai, S., 1994. Corn cystatin I expressed in Escherichia coli: investigation of its inhibitory profile and occurrence in corn kernals. J. Biochem. 116, 488-492.

Applebaum, S.W., 1985. Biochemistry of digestion. In:. Kerkut, G.A.,
Gilbert, L.I. (Eds.), Comparative Physiology, Biochemistry and Pharmacology of Insects, vol. 4. Pergamon Press, London, pp. 279-311.

Barlic-Maganja, D., Strukelj, B., Pungercar, J., Gubensek, F., Turk, V., Kregar, I., 1992. Isolation and sequence analysis of the genomic DNA fragment encoding an aspartic proteinase inhibitor homologue from potato (Solanum tuberosum L.). Plant Mol. Biol. 20, 311-313.

Barrett, A.J., 1977a. Introduction to the history and classification of tissue proteinases. In: Barrett, A.J. (Ed.), Proteinases of Mammalian Cells and Tissues. Elsevier/North-Holland Biomedical Press, Amsterdam, pp. 1-55.

Barrett, A.J., 1977b. Cathepsin D and other carboxyl proteinases. In: Barrett, A.J. (Ed.), Proteinases of Mammalian Cells and Tissues. Elsevier/North-Holland Biomedical Press, Amsterdam, pp. 209 248.

Barrett, A.J., 1986. The classes of proteolytic enzymes. In: Dalling, M.J. (Ed.), Plant Proteolytic Enzymes. CRC, Boca Raton, FL, pp. $1-16$.

Barrett, A.J., Kirschke, H., 1981. Cathepsin B, cathepsin H, and cathepsin L. Methods Enzymol. 80, 535-561.

Barrett, A.J., Kembhavi, A.A., Brown, M.A., Kirschke, H., Knight, C.G., Tamai, M., Hanada, K., 1982. L-trans-Epoxysuccinylleucylamido(4-guanidino)butane (E-64) and its analogues as inhibitors of cysteine proteinases including cathepsins $\mathrm{B}, \mathrm{H}$ and $\mathrm{L}$. Biochem. J. 201, 189-198.

Bonade-Bottino, M., Lerin, J., Zaccomer, B., Jouanin, L., 1999. Physiological adaptation explains the insensitivity of Baris coerulescens to transgenic oilseed rape expressing oryzacystatin I. Insect Biochem. Molec. Biol. 29, 131-138.

Broadway, R.M., 1995. Are insects resistant to proteinase inhibitors? J. Insect Physiol. 41, 107-116.

Broadway, R.M., 1996a. Resistance of plants to herbivorous insects: can this resistance fail? Can. J. Plant Pathol. 18, 476-481.

Broadway, R.M., 1996b. Dietary proteinase inhibitors alter complement of midgut proteases. Arch. Insect Biochem. Physiol. 32, 39-52.

Broadway, R.M., 1997. Dietary regulation of serine proteinases that are resistant to serine proteinase inhibitors. J. Insect Physiol. 43, 855-874.

Brown, D.P., Wilkinson, H.S., Gatehouse, J.A., 1997. Differentially regulated inhibitor-sensitive and insensitive protease genes from the phytophagous insect pest, Helicoverpa armigera, are members of complex multigene families. Insect Biochem. Molec. Biol. 27, 625-638.

Brzin, J., Popovic, T., Ritonja, A., Puizdar, V., Kidric, M., 1998. Related cystatin inhibitors from leaf and from sead Phaseolus vulgaris L. Plant Science 138, 17-26.

Christeller, J.T., Shaw, B.D., Gardiner, S.E., Dymock, J., 1989. Partial purification and characterization of the major midgut proteases of grass grub larvae (Costelytra zealandica, Coleoptera: Scarabaeidae). Insect Biochem. 19, 221-231.

Christeller, J.T., Laing, W.A., Markwick, N.P., Burgess, E.P.J., 1992. Midgut protease activities in 12 phytophagous Lepidoptera larvae: dietary and protease inhibitor interactions. Insect Biochem. Molec. Biol. 22, 735-746.

Christeller, J.T., Farley, P.C., Ramsay, R.J., Sullivan, P.A., Laing, W.A., 1998. Purification, characterization and cloning of an aspartic proteinase inhibitor from squash phloem exudate. Eur. J. Biochem. 254, 160-167.

Cloutier, C., Fournier, M., Jean, C., Yelle, S., Michaud, D., 1999. Growth compensation and faster development of colorado potato beetle (Coleoptera: Chrysomelidae) feeding on potato foliage expressing oryzacystatin I. Arch. Insect Biochem. Physiol. 40, 69-79.

Elden, T.C., 1995a. Effects of dormancy and photoperiod on alfalfa 
weevil (Coleoptera: Curculionidae) redproductive diapause. J. Entomol. Sci. 30, 481-488.

Elden, T.C., 1995b. Selected proteinase inhibitor effects on alfalfa weevil (Coleoptera: Curculionidae) growth and development. J. Econ. Entomol. 88, 1586-1590.

Girard, C., Le Metayer, M., Bonade-Bottino, M., Pham-Delegue, M.H., Jouanin, L., 1998a. High level of resistance to proteinase inhibitors may be conferred by proteolytic cleavage in beetle larvae. Insect Biochem. Molec. Biol. 28, 229-237.

Girard, C., Le Metayer, M., Zaccomer, B., Bartlet, E., Williams, I., Bonade-Bottino, M., Pham-Delegue, M.-H., Jouanin, L., 1998 b. Growth stimulation of beetle larvae reared on transgenic oilseed rape expressing a cysteine proteinase inhibitor. J. Insect Physiol. 44, 263-270.

Giri, A.P., Harsulkar, A.M., Deshpande, V.V., Sainani, M.N., Gupta, V.S., Ranjekar, P.K., 1998. Chickpea digestive proteinase inhibitors can be inactivated by podborer gut proteinases. Plant Physiol. 116, 393-401.

Green, T.R., Ryan, C.A., 1972. Wound-induced proteinase inhibitors in plant leaves: a possible defense mechanism against insects. Science 175, 776-777.

Hanada, K., Tamai, M., Yamagishi, M., Ohmura, S., Sawada, J., Tanaka, I., 1978. Isolation and characterization of E-64, a new thiol protease inhibitor. Agric. Biol. Chem. 42, 523-528.

Houseman, J.G., Downe, A.E.R., 1983. Cathepsin D-like activity in the posterior midgut of Hemipteran insects. Comp. Biochem. Physiol. 75B, 509-512.

Jongsma, M.A., Bakker, P.L., Peters, J., Bosch, D., Stiekema, W.J., 1995. Adaptation of Spodoptera exigua larvae to plant proteinase inhibitors by induction of gut proteinase activity insensitive to inhibition. Proc. Natl. Acad. Sci. 92, 8041-8045.

Jongsma, M.A., Bolter, C., 1997. The adaptation of insects to plant protease inhibitors. J. Insect Physiol. 43, 885-895.

Jouanin, L., Bonade-Bottino, M., Girard, C., Morrot, G., Giband, M., 1998. Transgenic plants for insect resistance. Plant Science 131, $1-11$.

Keilova, H., Tomasek, V., 1976a. Further characteristics of cathepsin D inhibitor from potatoes. Collection Czechoslov. Chem. Commun. 41, 2440-2447.

Keilova, H., Tomasek, V., 1976b. Isolation and some properties of cathepsin D inhibitor from potatoes. Collection Czechoslov. Chem. Commun. 41, 489-497.

Kondo, H., Abe, K., Nishimura, I., Watanabe, H., Emori, Y., Arai, S., 1990. Two distinct cystatin species in rice seeds with different specificities against cysteine proteinases. J. Biol. Chem. 265, 15832-15837.

Kreft, S., Ravnikar, M., Mesko, P., Pungercar, J., Umek, A., Kregar, I., Strukelj, B., 1997. Jasmonic acid inducible aspartic proteinase inhibitors from potato. Phytochemistry 44, 1001-1006.

Mares, M., Meloun, B., Pavlik, M., Kostka, V., Baudys, M., 1989. Primary structure of cathepsin D inhibitor from potatoes and its structure relationship to soybean trypsin inhibitor family. FEBS Lett. 251, 94-98.

Michaud, D., Nguyen-Quoc, B., Yelle, S., 1994. Production of oryzacystatins I and II in Escherichia coli using the glutathione $S$-transferase gene fusion system. Biotechnol. Prog. 10, 155-159.

Michaud, D., Bernier-Vadnais, N., Overney, S., Yelle, S., 1995. Constitutive expression of digestive cysteine proteinase forms dur- ing development of the colorado potato beetle, Leptinotarsa decemlineata Say (Coleoptera: Chrysomelidae). Insect Biochem. Molec. Biol. 25, 1041-1048.

Murdock, L.L., Brookhart, G., Dunn, P.E., Foard, D.E., Kelley, S., Kitch, L., Shade, R.E., Shukle, R.H., Wolfson, J.L., 1987. Cysteine digestive proteinases in coleoptera. Comp. Biochem. Physiol. 87B, 783-787.

Orr, G.L., Strickland, J.A., Walsh, T.A., 1994. Inhibition of Diabrotica larval growth by a multicystatin from potato tubers. J. Insect Physiol. 40, 893-900.

Pernas, M., Sanchez-Monge, R., Gomez, L., Salcedo, G., 1998. A chestnut seed cystatin differentially effective against cysteine proteinases from closely related pests. Plant Molec. Biol. 38, 12351242.

Ratcliffe, R.H., Elgin, J.H., 1987. A seedling test to select for alfalfa weevil (Coleoptera: Curculionidae) resistance in alfalfa. J. Econ. Entomol. 80, 975-978.

Riemann, S., Kirschke, H., Wiederanders, B., Brouwer, A., Shaw, E., Bohley, P., 1982. Inhibition of cysteine proteinase activity by ZPhe-Phe-diazomethane and of aspartic proteinase activity by pepstatin in different organs of some animals and isolated cells from rat liver. Acta Biol. Med. Germ. 41, 83-88.

Ritonja, A., Krizaj, I., Mesko, P., Kopitar, M., Lucovnik, P., Strukelj, B., Pungercar, J., Buttle, D.J., Barrett, A.J., Turk, V., 1990. The amino acid sequence of a novel inhibitor of cathepsin D from potato. FEBS Lett. 267, 13-15.

Rowan, A.D., Mason, P., Mach, L., Mort, J.S., 1992. Rat procathepsin $\mathrm{B}$, proteolytic processing to the mature form in vitro. J. Biol. Chem. 267, 15993-15999.

Sarath, G., De La Motte, R.S., Wagner, F.W., 1989. Protease assay methods. In: Beynon, R.J., Bond, J.S. (Eds.), Proteolytic Enzymes: A Practical Approach. IRL Press, New York, pp. 25-55.

Schuler, T.H., Poppy, G.M., Kerry, B.R., Denholm, I., 1998. Insectresistant transgenic plants. Trends Biotechnol. 16, 168-175.

Shaw, E., Green, G.D.J., 1981. Inactivation of thiol proteases with peptidyl diazomethyl ketones. Methods Enzymol. 80, 821-826.

Storey, R.D., Wagner, F.W., 1986. Plant proteases: a need for uniformity. Phytochemistry 25, 2701-2709.

Strukelj, B., Pungercar, J., Mesko, P., Barlic-Maganja, D., Gubensek, F., Kregar, I., Turk, V., 1992. Characterization of aspartic proteinase inhibitors from potato at the gene, cDNA and protein levels. Biol. Chem. 373, 477-482.

Strukelj, B., Ravnikar, M., Mesko, P., Poljsak-Prijatelj, M., Pungercar, J., Kopitar, G., Kregar, I., Turk, V., 1995. Molecular cloning and immunocytochemical localization of jasmonic acid inducible cathepsin D inhibitors from potato. Adv. Exp. Med. Biol. 362, 293-298.

Terra, W.R., Ferreira, C., 1994. Insect digestive enzymes: properties, compartmentalization and function. Comp. Biochem. Physiol. 109B, 1-62.

Thie, N.M.R., Houseman, J.G., 1990. Identification of cathepsin B, D, and $\mathrm{H}$ in the larval midgut of colorado potato beetle, Leptinorarsa decemlineata Say (Coleoptera: Chrysomelidae). Insect Biochem. 20, 313-318.

Wu, Y., Llewellyn, D., Matthews, A., Dennis, A.S., 1997. Adaptation of Helicoverpa armigera (Lepidoptera: Noctuidae) to a proteinase inhibitor expressed in transgenic tobacco. Molecular Breeding 3, 371-380. 